\title{
PENGEMBANGAN MULTIMEDIA INTERAKTIF BERBASIS PROBLEM BASED LEARNING (PBL) UNTUK MENINGKATKAN KEMAMPUAN BERPIKIR KRITIS MAHASISWA PROGRAM STUDI PENDIDIKAN BIOLOGI UMS PADA MATERI SISTEM GERAK MANUSIA
}

\author{
Fatma Yuny Isnaneny ${ }^{1}$, Sajidan $^{2}$, dan Mohammad Masykuri ${ }^{3}$ \\ ${ }^{1}$ Magister Pendidikan Sains, Fakultas Keguruan dan Ilmu Pendidikan, Universitas Sebelas Maret \\ Surakarta, 57126, Indonesia \\ bio_alqudsy@yahoo.co.id \\ ${ }^{2}$ Magister Pendidikan Sains, Fakultas Keguruan dan Ilmu Pendidikan, Universitas Sebelas Maret \\ Surakarta, 57126, Indonesia \\ sajidan@fkip.uns.ac.id \\ ${ }^{3}$ Magister Pendidikan Sains, Fakultas Keguruan dan Ilmu Pendidikan, Universitas Sebelas Maret \\ Surakarta, 57126, Indonesia \\ mmasykuri@yahoo.com
}

\begin{abstract}
Abstrak
Penelitian ini bertujuan untuk : 1) Menyusun multimedia interaktif dengan karakteristik model PBL, 2) menguji kelayakan multimedia interaktif berbasis PBL, 3) menguji keefektifan multimedia interaktif berbasis PBL. Penelitian ini menggunakan metode pengembangan Borg \& Gall dengan 8 tahapan. Pengumpulan data menggunakan angket, lembar observasi, lembar wawancara dan tes kemampuan berpikir kritis. Data hasil kemampuan berpikir kritis dianalisis dengan uji t dan deskriptif kuantitatif, data kualitatif dianalisis dengan menggunakan teknik analisis data triangulasi, yaitu memadukan dan menggeneralisasikan hasil data dalam bentuk kalimat deskriptif secara terperinci dan apa adanya. Hasil validasi ahli dan praktisi memperoleh rataan 3,70 dengan kategori sangat baik. Hasil uji coba kelompok kecil memperoleh rataan nilai 3,22 dengan kategori baik. Uji coba operasional dengan quasi eksperimen menunjukkan hasil kemampuan berpikir kritis memberikan perbedaan signifikan yaitu nilai kelas uji coba lebih tinggi dibandingkan kelas kontrol. Persentase kemampuan berpikir kritis kelas uji coba $86,1 \%$ dengan kriteria kritis sekali dan kelas kontrol $57,7 \%$ kriteria cukup kritis, jadi ada peningkatan kemampuan berpikir kritis sebesar 28,4\%. Uji korelasi menunjukkan koefisien korelasi $+0,118$, apabila kemampuan berpikir kritis tinggi maka hasil belajar pun tinggi. Keterlaksanaan sintaks PBL dalam media sebesar 32,2 dan 82,97\%. Berdasarkan hasil penelitian dapat disimpulkan sebagai berikut: 1) Pengembangan multimedia interaktif berbasis PBL mempunyai karakteristik yaitu terdapat forum sajian masalah, terdapat penyelidikan autentik, melibatkan disiplin ilmu lain, terdapat fitur membuat hasil karya, terdapat review ahli, terdapat eksperimen baru, game edukasi PBL, 2) multimedia interaktif berbasis PBL layak digunakan pada proses pembelajaran. 3) multimedia interaktif berbasis PBL mampu meningkatkan kemampuan berpikir kritis mahasiswa.
\end{abstract}

Kata kunci : multimedia, interaktif, PBL, kemampuan berpikir kritis.

\section{Pendahuluan}

Pembelajaran biologi merupakan pembelajaran yang tidak hanya menghasilkan produk berupa konsep, prinsip, dan teori, akan tetapi juga membuat siswa melakukan proses sainsnya sehingga melahirkan sikap ilmiah. Tujuan dari pendidikan biologi yaitu memahami konsep-konsep biologi dan mengembangkan keterampilan dasar biologi untuk menumbuhkan nilai serta sikap ilmiah (Smarabawa, Arnyana, \& Setiawan, 2013).

Pembelajaran biologi saat ini masih berorientasi kepada produk, keberhasilan proses belajar diukur dari penguasaan siswa tentang materi pelajaran yang disampaikan dosen. Pada kenyataannya dosen dalam pembelajaran biologi masih mendominasi proses pembelajaran atau teacher centered 
learning. Hal ini penulis temukan pada saat observasi di Program Studi (Prodi) Pendidikan Biologi Universitas Muhammadiyah Surakarta (UMS), dosen dalam menyampaikan materi selalu dengan metode ceramah dan mahasiswa hanya mendengarkan materi yang disampaikan dosen. Teacher centered dimungkinkan memiliki efek negatif bagi mahasiswa dengan pengetahuan awal yang rendah (Lasry et al, 2014). Hal ini di perkuat oleh Hadi (2007) yang menyatakan bahwa sistem pembelajaran pada hampir semua program studi perguruan tinggi di Indonesia masih bersifat satu arah, yaitu pemberian materi oleh dosen. Sistem pembelajaran tersebut dikenal dengan model Teacher Centered Learning (TCL), yang ternyata membuat mahasiswa pasif karena hanya mendengarkan kuliah sehingga kreativitas mereka kurang terpupuk atau bahkan cenderung tidak kritis.

Kurikulum yang digunakan Prodi Pendidikan Biologi UMS adalah kurikulum 2007 yaitu pengembangan dari kurikulum 2002 yaitu Kurikulum Berbasis Kompetensi (KBK) yang terdiri dari 146 Sistem Kredit Semester (SKS). Sebelumnya kurikulum yang digunakan adalah kurikulum 1998 yang terdiri 160 SKS. Perubahan kurikulum ini menunjukkan bahwa Prodi Pendidikan Biologi UMS telah melakukan evaluasi kurikulum sebagai usaha untuk meningkatkan relevansi lulusan, pada kurikulum ini ditetapkan jenis mata kuliah yang harus diselesaikan (Tim Penyusun Kurikulum Prodi P. Biologi FKIP UMS, 2013).

Anatomi Fisiologi Manusia (Anfisman) merupakan salah satu mata kuliah di Prodi Pendidikan Biologi UMS yang menekankan pada cakupan materi yang sangat kompleks dan abstrak. Karakter materi yang sangat kompleks membuat mata kuliah Anfisman diselesaikan tuntas selama dua semester. Materi Anfisman dengan objek yang abstrak (tidak nyata) seharusnya disajikan kedalam pendekatan yang lebih konkret, ada visualisasinya, serta manfaat dalam mempelajari materi tersebut dalam kehidupan sehari-hari sehingga memberikan motivasi dosen agar selalu mengembangkan media yang cocok, hal ini tidak bisa dilakukan dosen secara instan akan tetapi perlu proses matang. Anfisman adalah salah satu mata kuliah yang penting di jurusan biologi dengan materi yang sulit dan abstrak, apabila dukungan media pembelajarn yang kurang akan mengakibatkan mahasiswa kesulitan dalam menerima materi (Rahayu et al, 2014).

Hasil data statistik nilai akhir Anfisman (2014) menunjukkan mata kuliah Anfisman terdiri dari 6 materi, untuk sistem gerak dibedakan menjadi dua sub materi yaitu sistem skeleton dan sistem musculus. Sub materi sistem skeleton memiliki nilai rata-rata terendah yaitu 38,1 sedangkan sistem musculus terendah ketiga yakni 46,6.

Hasil data analisis 8 Standar Nasional Pendidikan Tinggi (SNPT) mengindikasikan adanya kesenjangan pada proses pembelajaran biologi di Pendidikan Biologi UMS. Hasil analisis menunjukkan bahwa persentase kesenjangan yang tinggi terletak pada standar proses $(3,70 \%)$. Tingginya persentase kesenjangan pada standar proses memberikan indikasi bahwa terdapat pula kesenjangan dalam proses pembelajaran khususnya ketepatan pemilihan metode, modul atau medianya.

Hasil angket menunjukkan bahwa 93\% mahasiswa menjawab bahwa dosen lebih sering menggunakan media daripada modul maupun model. Media yang digunakan adalah media powerpoint yang berisi gambar dan text. Meskipun dosen sudah menggunakan media sebagai alat bantu mempermudah pemahaman mahasiswa, akan tetapi dosen masih menggunakan metode ceramah dan terlihat teacher centered learning. Hasil angket juga menunjukkan bahwa 59,6\% mahasiswa menginginkan peningkatan penggunaan multimedia interaktif, perkuliahan Anfisman lebih efektif apabila pembelajarannya menggunakan multimedia interaktif yang memungkinkan mahasiswa menjadi aktif bukan teacher centered learning lagi, hal ini dikarenakan materi pada Anfisman sangat kompleks dan abstrak. Materi kompleks membutuhkan waktu yang lama sedangkan abstrak membutuhkan visualisasi yang tepat. Multimedia pembelajaran secara interaktif 
memungkinkan pembelajaran yang berpusat pada siswa terjadi (Mayer, 2002).

Berdasarkan

SNPT

menegaskan bahwa lulusan pendidikan harus mampu melakukan pemikiran kritis terhadap hasil kerja dan keputusan yang dibuat oleh dirinya sendiri atau orang lain (Dirjen PT \& BSNP, 2014). Hal ini diperkuat hasil wawancara dengan dosen Anfisman UMS bahwa pembelajaran Anfisman dengan penanganan case memiliki tujuan untuk meningkatkan kemampuan berpikir kritis mahasiswa.

Hasil analisis kontrak belajar Anfisman menunjukkan bahwa pembelajaran Anfisman dibagi menjadi 2 yaitu pada Anfisman I ditekankan pada case dengan penanganan sederhana dan Anfisman II ditekankan pada basic science. Menurut keterangan dosen Anfisman, pada pembelajaran Anfisman I sudah pernah dilakukan latihan untuk penanganan sederhana akan kasus-kasus sehari-hari, akan tetapi hasil dari kegiatan ini belum mencapai target. Dosen Anfisman juga sudah memuatkan soal penanganan kasus pada soal UTS 1 dan UAS 1, akan tetapi hasilnya belum mencapai target juga. Data hasil rata-rata nilai soal case adalah 50,5, soal UTS 1 adalah 75,37, dan soal UAS 1 adalah 67,36 .

Salah satu alternatif model pembelajaran yang dapat meningkatkan kemampuan berpikir kritis adalah pembelajaran berbasis masalah (Problem Based-Learning/PBL). PBL merupakan strategi instruksional yang membuat siswa dapat mengembangkan kemampuan berpikir kristis dan keterampilan memecahkan masalah yang dapat mereka temukan dalam kehidupan sehari-hari (Fallis, 2013). Hasil angket menunjukkan bahwa 57,9\% mahasiswa Prodi Biologi UMS memilih PBL sebagai model pembelajran yang paling efektif dalam pembelajaran Anfisman. Mereka yakin dengan bantuan PBL pemikiran mahasiswa jauh lebih tinggi dibanding untuk menghadapi masalah keseharian.

Pengembangan multimedia interaktif berbasis PBL diharapkan dapat membuat mahasiswa menemukan masalahanya sendiri dan memecahkan masalah dengan proses sains, selain itu interaksi antara mahasiswa dan materi dapat efektif dan menciptakan pembelajaran Anfisman yang berpusat pada mahasiswa atau student centered learning.

Penelitian pengembangan ini memiliki tujuan untuk menyusun multimedia interaktif dengan karakteristik model PBL, menguji kelayakan, dan menguji keefektifan produk multimedia interaktif berbasis PBL.

\section{Metode Penelitian}

Tahap pengembangan dan validasi produk dilakukan di Universitas Sebelas Maret (UNS), Semarang, Kendal, dan UMS, sedangkan tahap uji coba kelompok kecil dan uji coba lapangan dilaksanakan di UMS. Penelitian dilaksanakan dari September 2013 sampai dengan Maret 2015. Pengembangan multimedia interaktif berbasis PBL menggunakan model Borg and Gall yang dengan 8 tahapan.

\section{A. Prosedur Pengembangan}

Prosedur pengembangan memakai model Borg and Gall (1983) dengan 8 tahapan yang dapat dilihat pada Gambar 1 berikut.

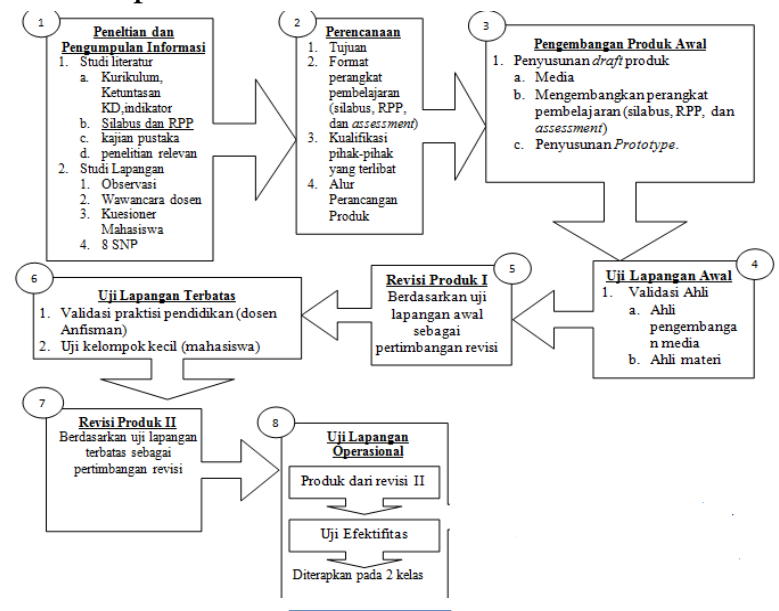

Gambar 1. R\&D 8 Tahapan dari Borg\&Gall (1983)

\section{B. Uji Coba Produk}

Uji coba dimaksudkan untuk mengumpulkan data terkait dengan produk yang dikembangkan yaitu multimedia interaktif berbasis PBL sehingga diketahui keefektifan 
dan keunggulan dari produk yang dihasilkan. Tahapan uji coba produk yaitu:

a) Validasi Ahli terdiri dari ahli materi biologi dan ahli pengembangan model.

b) Uji Coba Kelompok Kecil terdiri dari uji coba oleh dosen Anfisman dan mahasiswa.

c) Uji Coba Lapangan dilakukan pada kelas biologi UMS. Uji coba lapangan ini merupakan penelitian quasi eksperimen. Penelitian menggunakan dua kelas yaitu kelas kontrol (metode ceramah) dan kelas eksperimen (multimedia interaktif berbasis PBL) dilakukan pemberian soal untuk mengukur Kemampuan Berpikir Kritis (KBK) pada kedua kelompok tersebut. Desain penelitian yang digunakan dalam uji coba lapangan ini adalah Non Equivalent Post-Test Only Control Group Design (Sukardi, 2012: 173) yang ditampilkan pada Tabel 1.

\begin{tabular}{lcc}
\multicolumn{3}{c}{ Tabel 1. Desain Penelitian } \\
\hline Kelompok & Treatmen & Post-Test \\
\hline Kontrol & $\mathrm{X}_{1}$ & $\mathrm{O}_{1}$ \\
Eksperimen & $\mathrm{X}_{2}$ & $\mathrm{O}_{2}$ \\
\hline & \multicolumn{2}{c}{ Sumber: Sukardi $(2012: 173)$}
\end{tabular}

Keterangan :

$\mathrm{X}_{1}$ : Perlakuan kelompok kontrol

$\mathrm{X}_{2}$ : Perlakuan kelompok eksperimen

$\mathrm{O}_{1}$ : Post-Test soal KBK kelompok kontrol

$\mathrm{O}_{2}$ : Post-Test soal KBK kelompok eksperimen

\section{Pengumpulan dan Pengolahan Data}

Instrumen yang digunakan untuk mengumpulkan data dalam penelitian ini yaitu lembar wawancara, angket, lembar observasi, dan tes.

Data kualitatif yang diperoleh pada saat uji coba kelompok kecil berupa wawancara dianalisis secara deskriptif kualitatif, sedangkan perolehan data dari angket dikonversi ke tabel skala. Skor yang diperoleh kemudian dikonversikan menjadi data kualitatif skala empat yang diacu dari (Millah dkk (2012) yang dapat dilihat pada Tabel 2.

Tabel 2. Data Kualitatif Skala Empat

\begin{tabular}{clcc}
\hline Nilai & \multicolumn{1}{c}{ Kriteria } & \multicolumn{2}{c}{ Skor } \\
\hline & & Angka & Perhitungan \\
\hline A & Sangat Baik & 4 & $3,51-4,00$ \\
B & Baik & 3 & $2,51-3,50$ \\
C & Kurang Baik & 2 & $1,51-2,50$ \\
D & Tidak Baik & 1 & $1,00-1,50$ \\
\hline & & Sumber: Millah dkk (2012: 24$)$
\end{tabular}

Penelitian ini juga menggunakan analisis kuantitatif untuk mengukur keefektifan multimedia interaktif berbasis PBL dalam meningkatkan kemampuan berpikir kritis mahasiswa. Uji efektivitas yang dilakukan dikemas dalam seting eksperimen. Teknik analisis statistik yang digunakan adalah dengan uji $\mathrm{t}$ ( $t$ test) menggunakan bantuan program analisis SPSS 20 yang didahului dengan uji prasyaratnya yaitu uji homogenitas dan uji normalitas (Santoso, 2015: 189).

Analisis untuk mengukur kemampuan berpikir kritis mahasiswa diperoleh dari hasil tes kemampuan berpikir kritis dilihat dari skor yang diperoleh mahasiswa dalam mengerjakan soal tes kemampuan berpikir kritis. Skor yang diperoleh mahasiswa, kemudian dihitung persentasenya untuk mengukur kemampuan berpikir kritisnya (Lewy et al, 2009). Sistem penskoran tingkat kemampuan berpikir kritis dapat dilihat pada Tabel 3.

\begin{tabular}{|c|c|}
\hline Skor & Kriteria \\
\hline 4 & Tampak 3 deskriptor \\
\hline 3 & Tampak 2 deskriptor \\
\hline 2 & Tampak 1 deskriptor \\
\hline 1 & Tampak 0 deskriptor \\
\hline
\end{tabular}

Skor kemampuan berpikir kritis dari masing-masing mahasiswa adalah jumlah skor yang diperoleh sesuai dengan banyaknya deskriptor yang tampak pada saat menyelesaikan soal tes kemampuan berpikir kritis. Skor maksimum adalah skor tertinggi (skor 4) dikalikan dengan jumlah soal (12 butir soal), skor maksimumnya adalah $4 \times 12=48$, sedangkan skor minimumnya adalah $1 \times 12=$ 12, sehingga interval skor rata-rata kemampuan berpikir kritis $48-12=36$, peneliti membagi interval menjadi 4 selang dengan rentang 9 (Lewy et al, 2009).

Data hasil tes kemudian dianalisis untuk menetukan rata-rata skor akhir pada akhir pertemuan dan kemudian dikonversi kedalam data kualitatif untuk menentukan kategori tingkat kemampuan berpikir kritis mahasiswa (Lewy et al, 2009). Kategori tingkat kemampuan berpikir kritis ditentukan pada seperti pada Tabel 4. 
Tabel 4 Kategori Tingkat Berpikir Kritis.

\begin{tabular}{cc}
\hline Nilai Siswa & Kategori \\
\hline $39-48$ & Sangat Baik \\
$30-38$ & Baik \\
$21-29$ & Cukup \\
$12-20$ & Kurang \\
\hline & Sumber: Lewy et al, 2009
\end{tabular}

Data nilai siswa di atas dijadikan nilai persentase dengan menggunakan rumus:

$$
\text { Persentase }(100 \%)=\frac{\sum \text { skor }}{\sum \text { skormaks }} \times 100 \%
$$

Sumber: adaptasi dari Arikunto, (2001: 236)

Kriteria persentase keterlaksanaan tes kemampuan berpikir kritis dapat dilihat pada Tabel 5 sebagai berikut.

Tabel 5 Kriteria Kemampuan Berpikir Kritis

\begin{tabular}{cc}
\hline Persentase (\%) & Kriteria \\
\hline $81 \%-100 \%$ & Kritis Sekali \\
$66 \%-80 \%$ & Kritis \\
$56 \%-65 \%$ & Cukup Kritis \\
$41 \%-55 \%$ & Kurang Kritis \\
$0 \%-40 \%$ & Tidak Kritis \\
\hline \multicolumn{2}{r}{ Sumber: adaptasi dari Arikunto, (2001: 236) }
\end{tabular}

\section{Hasil Penelitian dan Pembahasan}

\section{A. Tahap Penelitian dan Pengumpulan Data Awal.}

Kegiatan pada tahap ini adalah studi lapangan didapatkan hasil analisis kurikulum yaitu telajh dilakukan pengembangan kurikulum 2007, analisis ketuntasan KD dan indikator didapatkan materi sitem gerak manusia memiliki rata-rata terendah yaitu 38,1 , analisis silabus didapatkan hasil yang sudah sesuai dengan aturan silabus yang ada, analisis Rencana Pelaksanaan Pembelajaran (RPP) diadapatkan informasi bahwa dosen tidak membuat RPP, observasi kelas didapatkan proses pembelajaran masih teacher centered, analisis media didapatkan pembelajaran Anfisman lebih sering memakai media powerpoint (93\%) dan mahasiswa menginginkan multimedia yang lebih interaktif $(59,6 \%)$, analisis kemampuan berpikir kritis didapatkan data nilai rata-rata soal kemampuan berpikir kritis pada soal case 50,5 soal UTS 1 75,37 dan soal UAS 1 67,36, analisis PBL didapatkan bahwa PBL merupakan model yang paling efektif untuk meningkatkan kemampuan berpikir kritis $(57,9 \%)$ dan analisis 8 Standar Nasional Pendidikan Tinggi (SNPT) didapatkan GAP terting 3,7\% terletak pada standar proses.

\section{B. Tahap Perencanaan}

Hasil tahap perencanaan adalah tujuan pembelajaran, format perangkat pembelajaran, desain produk, kualifikasi pihak-pihak yang terlibat, dan prosedur penelitian hanya sampai pada tahap kedelapan.

\section{Tahap Pengembangan Produk Awal}

Tahap ini dihasilkan buku Prototype multimedia interaktif berbasis PBL dan karakteristik dari produk multimedia interaktif berbasis PBL yaitu terdapat forum sajian masalah, terdapat kegiatan penyelidikan autentik, melibatkan disiplin ilmu lain, terdapat fitur membuat hasil karya yang dapat dipamerkan, terdapat video review dari ahli permasalahan, terdapat eksperimen baru yang berhubungan dengan kehidupan sehari-hari dan terdapat game edukasi berbasis PBL.

Tipe prototype yang dibuat adalah prototype non computer jenis storyboard. Storyboard berisi desain tekstual dari desain sistem. Selain storyboard, prototype ditambahkan dengan ulasan pengenalan prototype, kebutuhan user, materi multimedia interaktif, model problem based learning, teori-teori belajar yang mendukung PBL, teori belajar orang dewasa, multimedia interaktif berbasis PBL, tugas guru dalam pembelajaran multimedia interaktif berbasis PBL, sistem sosial dan pendukung, dampak instruksional dan pengiring, serta pengembangan prototype.

\section{Tahap Uji Coba Lapangan Awal}

\section{Hasil Validasi Ahli Media}

Hasil validasi ahli media dapat dilihat pada Tabel 6 dan untuk mengetahui rata-rata nilai per Aspek dapat dilihat pada Gambar 3.

Tabel 6. Hasil Validasi Ahli Media

\begin{tabular}{|c|c|c|c|}
\hline Validator & Nilai & Kategori & Keterangan \\
\hline 1 & 3,87 & Sangat Baik & Dapat \\
\hline 2 & 3,71 & Sangat Baik & $\begin{array}{l}\text { diimplementasikan } \\
\text { Dapat } \\
\text { diimplementasikan }\end{array}$ \\
\hline
\end{tabular}




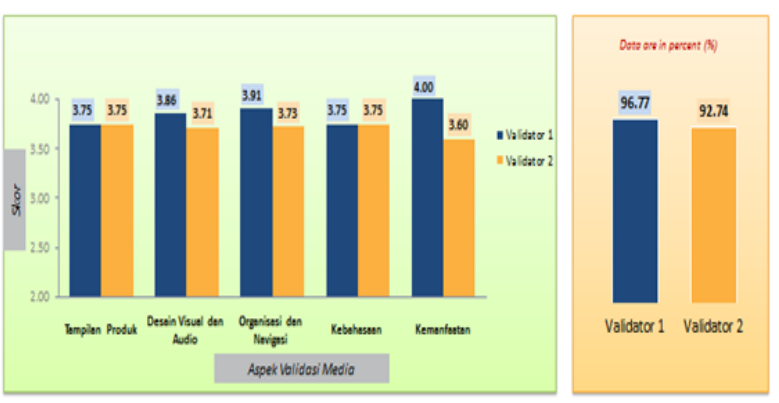

Gambar 3. Hasil Validasi Media Tiap Aspek

Tabel 6 maupun Gambar 3 menunjukkan bahwa ahli media memberikan nilai dengan kategori sangat baik.

\section{Hasil Validasi Materi}

Hasil validasi ahli materi dapat dilihat pada Tabel 7 dan untuk mengetahui rata-rata nilai per Aspek dapat dilihat pada Gambar 4.

Tabel 7. Hasil Validasi Materi

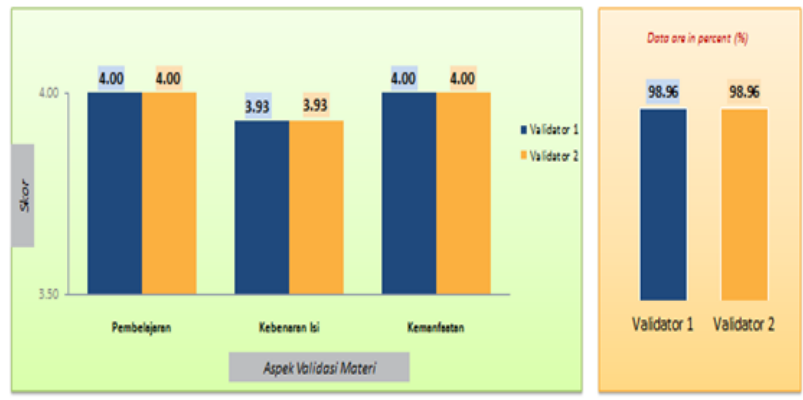

Gambar 4. Hasil Validasi Materi Tiap Aspek

Tabel 7 maupun Gambar 4 menunjukkan bahwa ahli materi memberikan nilai dengan kategori sangat baik.

\section{Hasil Validasi Perangkat}

Hasil validasi perangkat dapat dilihat pada Tabel 8.

Tabel 8. Hasil Validasi Perangkat

\begin{tabular}{cccc}
\hline Aspek & Nilai & Kategori & Keterangan \\
\hline Silabus & 3,20 & Baik & Dapat diimplementasikan \\
RPP & 3,21 & Baik & Dapat diimplementasikan \\
Evaluasi & 3,06 & Baik & Dapat diimplementasikan \\
Assessment & 3,06 & Baik & Dapat diimplementasikan \\
\hline
\end{tabular}

Tabel 8 menunjukkan bahwa ahli perangkat memberikan nilai dengan kategori baik.

\section{E. Tahap Revisi Produk I}

Tahap ini dihasilkan adanya kegiatan perbaikan tentang suara narrator, navigasi, default volume, tujuan pembelajaran dan soal evaluasi.

\section{F. Tahap Uji Coba Lapangan Terbatas}

1. Hasil Validasi Praktisi (Dosen Anfisman) Hasil validasi praktisi dapat dilihat pada Tabel 9 dan hasil validasi tiap aspek dilihat pada Gambar 5.

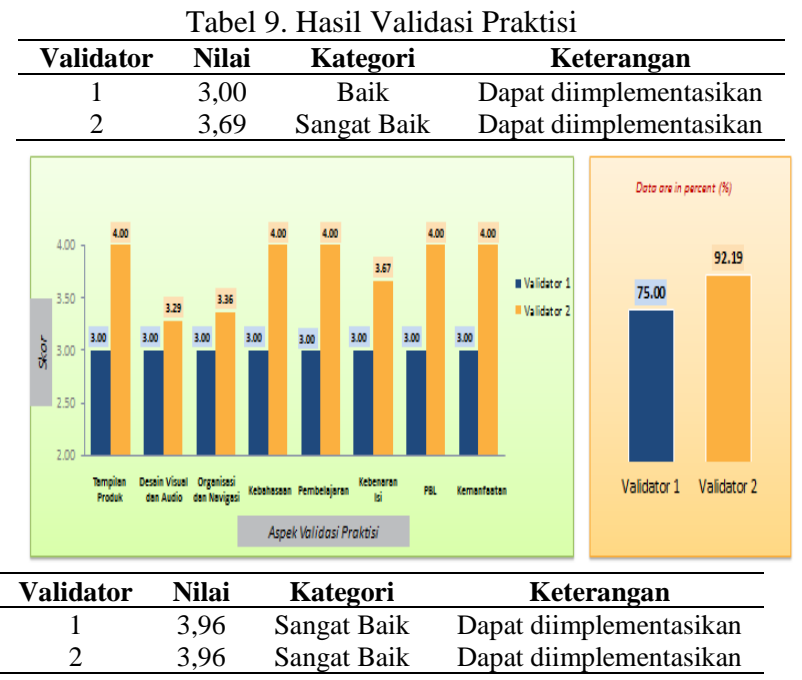

Gambar 5. Hasil Validasi Praktisi Tiap Aspek

Tabel 9 maupun Gambar 5 menunjukkan bahwa ahli materi memberikan nilai dengan kategori baik dan sangat baik

2. Uji Coba Kelompok Kecil

Pada uji coba kelompok kecil didapatkan hasil kuesioner mahasiswa yang dapat dilihat pada Tabel 10.

Tabel 10. Hasil Kuesioner Kelompok Kecil

\begin{tabular}{lcccc}
\hline \multicolumn{1}{c}{ Aspek } & Rata2 & Kategori & $\mathbf{( \% )}$ & Kategori \\
\hline Tampilan Produk & 3,18 & Baik & 79,5 & Tidak revisi \\
Visual dan Audio & 3,20 & Baik & 80 & Tidak revisi \\
OrganisasiNavigasi & 3,19 & Baik & 79,8 & Tidak revisi \\
Kebahasaan & 3,26 & Baik & 81,5 & Tidak revisi \\
Pembelajaran & 3,21 & Baik & 80,1 & Tidak revisi \\
Kebenaran isi & 3,20 & Baik & 80 & Tidak revisi \\
PBL & 3,12 & Baik & 78 & Tidak revisi \\
Kemanfaatan & 3.37 & Baik & 84,3 & Tidak revisi \\
\hline Rata-Rata Total & $\mathbf{3 , 2 2}$ & Baik & $\mathbf{8 0 , 4}$ & Tidak revisi \\
\hline
\end{tabular}

Tabel 10 menunjukkan bahwa produk multimedia interaktif berbasis PBL tidak perlu dilakukan revisi karena dalam kategori baik. Meskipun demikian beberapa mahasiswa masih memberikan saran membangun yang dijadikan pertimbangan pada tahap revisi II. 


\section{G. Revisi Produk II}

Tahap ini dihasilkan adanya kegiatan perbaikan navigasi yang perlu ditambah lagi.

\section{H. Tahap Uji Lapangan Operasional}

Hasil uji statistik tentang kemampuan berpikir ktitis (KBK) dilihat pada Tabel 11.

\begin{tabular}{|c|c|c|c|}
\hline Uji & Hasil & Keputusan & Kesimpulan \\
\hline \multirow[b]{2}{*}{ Normalitas } & $\begin{array}{l}\text { Sig. Kontrol } \\
=0,123\end{array}$ & $\begin{array}{l}\mathrm{H} 0 \\
\text { diterima }\end{array}$ & Data Normal \\
\hline & $\begin{array}{ll}\text { Sig. } & \text { Uji } \\
\text { Coba } & = \\
0,011 & \end{array}$ & H0 ditolak & Tidak Normal \\
\hline Homogenitas & $\begin{array}{l}\text { Mean data } \\
\text { Sig. }=0,012\end{array}$ & H0 ditolak & Tidak Homogen \\
\hline $\begin{array}{l}\text { Perbandingan } \\
\text { Rata-Rata } \\
\text { Populasi }\end{array}$ & Sig. 0,000 & H0 ditolak & $\begin{array}{l}\text { Rata-rata kedua } \\
\text { populasi } \\
\text { berbeda }\end{array}$ \\
\hline $\begin{array}{l}\text { Korelasi } \\
\text { KBK dan } \\
\text { Hasil Belajar }\end{array}$ & $+0,118$ & $\begin{array}{l}\text { Ada } \\
\text { Korelasi }\end{array}$ & $\begin{array}{l}\text { KBK tinggi, } \\
\text { hasil belajar pun } \\
\text { tinggi, dan } \\
\text { sebaliknya }\end{array}$ \\
\hline
\end{tabular}

Hasil rata-rata dari kedua kelas dapat dilihat pada Tabel 12.

Tabel 12. Hasil Rata-Rata Nilai

\begin{tabular}{cccc}
\hline kelas & Jumlah Siswa & Rerata & $\begin{array}{c}\text { Peningkatan } \\
(\mathbf{\%})\end{array}$ \\
\hline kontrol & 26 & 57,7 & 28,4 \\
\hline uji coba & 21 & 86,1 & 28,4 \\
\hline
\end{tabular}

Hasil kemampuan berpikir kritis menunjukkan bahwa kelas uji coba yang mempraktekkan multimedia interaktif berbasisi PBL memperoleh nilai yang lebih tinggi dibandingkan dengan kelas kontrol yang menggunakan metode ceramah. Selain itu multimedia interaktif berbasis PBL berhasil meningkatkan kemampuan berpikir kritis mahasiswa sebesar $28,4 \%$.

Hasil kemampuan berpikir kritis tiap-tiap indikator dapat dilihat pada Gambar 6 berikut.

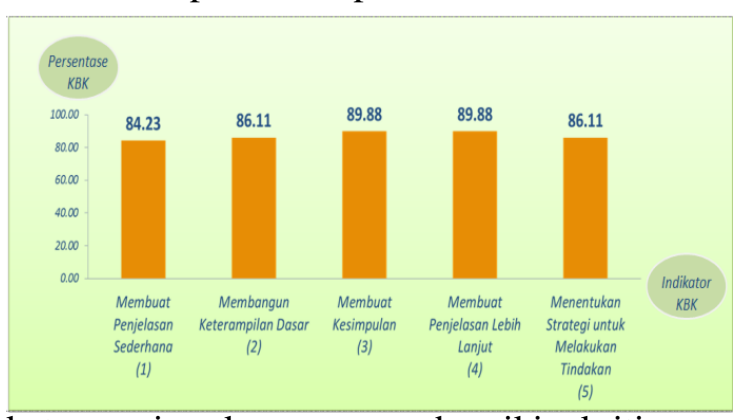

ketercapaian kemampuan berpikir kritis per indikator didapatkan hasil rata-rata persentase terendah pada indikator yang pertama yaitu membuat penjelasan sederhana sebesar 84,23\%. Menurut Lestari (2014: 43) menemukan bahwa rendahnya kemampuan membangun keterampilan dasar (basic support) mengindikasikan bahwa siswa masih kesulitan dalam memecahkan masalah yang memerlukan penalaran logis. Hal ini sejalan dengan hasil penelitian TIM Survey IMSTEP-JICA (Liliasari, 2000) di kota Bandung bahwa salah satu kegiatan terkait berpikir kritis yang dianggap sulit oleh siswa untuk mempelajarinya adalah kegiatan pemecahan masalah yang memerlukan penalaran logis dan menemukan generalisasi, agar dapat memberikan penjelasan sederhana siswa perlu memiliki wawasan yang luas terhadap sesuatu permasalahan yang logis. Wawasan yang luas dapat dibangun jika siswa memiliki kemampuan koneksi logis yang baik.

Hasil uji keterlaksanaan sintaks PBL di dalam multimedia interaktif berbasis PBL dengan menggunakan lembar observasi telah menunjukkan bahwa pembelajaran sudah berlangsung sesuai langkah-langkah pembelajaran PBL. Keterlaksanaan sintaks pembelajaran PBL berdasarkan hasil observasi yang telah dilakukan adalah $82,97 \%$. Persentase tersebut menunjukkan bahwa semua sintaks telah terlaksana dengan baik dalam pembelajaran. Nilai rata-rata keterlaksanaan sintaks PBL menghasilkan nilai sebesar 3,32, hal ini dapat disimpulkan bahwa keterlaksanaan sintaks PBL di dalam multimedia interaktif berbasis PBL baik dan sudah dapat dikatakan efektif. Nilai rata-rata keterlaksanaan proses pembelajaran dengan menggunakan model pembelajaran tertentu berkisar 2,5 - 4 maka proses pembelajaran tersebut dapat dikatakan sudah efektif (Sugiarto, 2013).

Ikhsan dan Rizal (2014) menemukan bahwa terjadi peningkatan kemampuan berpikir kritis siswa di kelas PBM (Pembelajaran Berbasis Masalah) daripada kelas konvensional. Hal ini diperkuat oleh jurnal dari Dwijananti dan Yulianti (2010: 108) yang menyatakan bahwa kemampuan berpikir kritis mahasiswa dapat dikembangkan pada model pembelajaran PBL yaitu mengklasifikasi, mengasumsi, memprediksi, 
menghipotesis, mengevaluasi, menganalisis, dan membuat kesimpulan. Seperti yang di paparkan oleh Hillman (2003) bahwa Problem Based Learning (PBL) berpotensi dapat menempatkan pelajar diposisi yang sama dengan ilmuwan dan proses ilmiah. Multimedia interaktif berbasis PBL mengedepankan karakteristik multimedia interaktif digabung dengan model PBL yang diyakini mampu meningkatkan kemampuan berpikir kritis. Indriana Fristanti (2011) dalam penelitiannnya membuktikan model Problem Based Learning (PBL) dapat meningkatkan kemampuan berpikir kritis siswa dalam mengikuti pelajaran IPS. Persson et al (2010) menyatakan bahwa menambahkan multimedia untuk skenario PBL membuat siswa lebih realistis dan dengan demikian lebih memotivasi dan merangsang bagi siswa untuk memproses. Proses kelompok tidak terganggu oleh pengenalan komputer di ruang kelompok. Hal ini penting untuk menantang siswa dengan memvariasikan perspektif dan desain skenario dalam rangka untuk menjauhkan dari perilaku yang mungkin proses pembelajaran.

Hasil dari penelitian ini membuktikan bahwa multimedia interaktif berbasis PBL yang dikembangkan mampu meningkatkan kemampuan berpikir kritis mahasiswa. Model PBL dengan karakteristiknya yang menekankan pada suatu kasus dan problem solving yang autentik dipercaya membangun potensi berpikir dan rasa ingin tahu untuk memecahkan masalah yang ditemukan tersebut. Park and Ertmer (2007) menyatakan bahwa pendekatan pembelajaran PBL dimulai dengan masalah yang autentik dan terstruktur yang menuntut siswa untuk mengembangkan keahlian dalam mencari informasi dan pengambilan keputusan untuk memecahkan masalah. Dengan demikian, PBL diyakini dapat meningkatkan kemampuan berpikir kritis siswa, meningkatkan motivasi, dan meningkatkan keterampilan sosial melalui kerja kelompok. Agnes \& Patrick (2006) menambahkan bahwa meskipun latar belakang pendidikan siswa didominasi oleh guru (teacher oriented), siswa masih mampu menunjukkan kemampuan untuk mempertahankan kemampuan diri dan memperoleh kemampuan berpikir kritis selama proses PBL.

Afcariono (2008) menunjukkan bahwa problem solving mampu meningkatkan kemampuan berpikir siswa seperti kemampuan bertanya dan menjawab permasalahan yang akan dipecahkan. Penelitian lain yang pernah dilakukan oleh Adnyana (2009) juga menunjukkan bahwa penerapan model pemecahan masalah (problem solving) mampu menciptakan interaksi belajar siswa yang sangat dinamis dan kerjasama antar siswa dalam kelompok maupun antar kelompok yang lebih baik. Demir et al (2011) memaparkan bahwa konsep berpikir dan problem solving mengandung arti yang sangat signifikan dalam berpikir kritis. Lai (2011) menambahkan bahwa berpikir kritis meliputi keterampilan komponen menganalisis argumen, membuat kesimpulan menggunakan penalaran induktif atau deduktif , menilai atau mengevaluasi, dan membuat keputusan atau pemecahan masalah. Jadi pembelajaran PBL memang sangat dipercaya untuk meningkatkan kemampuan berpikir kritis siswa karena karakteristik PBL yang memunculkan suatu permasalahan yang autentik dan harus diselesaikan secara autentik juga.

Berpikir kritis sangat penting untuk diajarkan kepada mahasiswa agar dapat memperoleh, mengembangkan dan berlatih untuk menghubungkan pernyataan-pernyataan masalah yang dihadapi mereka (Wilson, 2012). Hal ini diperkuat oleh Berlet (2014) yang menyatakan bahwa berpikir kritis merupakan kegiatan mengorganisasikan dan mengaitkan hubungan antara ide-ide atau informasiinformasi. Berpikir kritis adalah keterampilan yang kebanyakan guru akan langsung setuju bahwa sangat penting dikembangkan bagi siswa, kita harus berkomitmen untuk mengembangkan pemecahan masalah dan pengambilan keputusan melalui pengajaran keterampilan berpikir kritis (Rudd, 2011). Jadi dari pemaparan hasil penelitian beberapa peneliti di atas dapat dikatakan bahwa melatih dan mengembangkan kemampuan berpikir kritis sangat penting untuk dilakukan oleh seorang dosen kepada mahasiswanya agar dapat menemukan masalah dan memperoleh 
solusi dari kegiatan mengaitkan informasiinformasi atau ide-ide yang ada secara tepat dan benar, sehingga mahasiswa diharapkan mampu dalam menghadapi masalah dalam kehidupan nyatanya dan menemukan sendiri solusi yang tepat.

\section{Kesimpulan dan Rekomendasi}

Pengembangan multimedia interaktif berbasis PBL pada materi sistem gerak manusia mempunyai karakteristik spesifik yaitu terdapat forum sajian masalah, terdapat kegiatan penyelidikan autentik, melibatkan i karya yang dapat dipamerkan, terdapat video review dari ahli permasalahan, terdapat eksperimen baru yang berhubungan dengan kehidupan sehari-hari, terdapat game edukasi berbasis PBL.

Hasil pengembangan multimedia interaktif berbasis PBL pada materi sistem gerak manusia layak untuk mendukung pembelajaran pada materi tersebut.

Multimedia interaktif berbasis PBL mampu meningkatkan kemampuan berpikir mahasiswa.

\section{Daftar Pustaka}

Adnyana, G. P. 2009. Meningkatkan Kualitas Aktivitas Belajar, Keterampilan Berpikir Kritis, dan Pemahaman Konsep Biologi Siswa Kelas X-5 SMA Negeri 1 banjar Melalui Penerapan Model Pembelajaran Pemecahan Masalah. Jurnal Pendidikan Kerta Mandala. 1 (1): 54-69.

Afcariono, M. 2008. Penerapan Pembelajaran Berbasis Masalah untuk Meningkatkan Kemampuan Berpikir Siswa pada Mata Pelajaran Biologi. Jurnal Pendidikan Inovatif. 3 (2): 65-68.

Agnes, Tiwari \& Patrick, Lai. 2006. A Comparison of the Effects of Problem Based Learning and Lecturing on the Development of Student Critical Thinking. Journal of Medical Education. 40 (6): 547-554.

Arikunto, Suharsimi. 2001. Prosedur Penelitian: Suatu Pendekatan Praktek. Jakarta: Rineka Cipta.
Berlet, Gregory C. 2014. Critical Thinking. Journal of Foot \& Ankle Specialist. 7 (2): 94.

Borg, W. R. \&Gall, M. D. 1983. Educational Research an Introduction. New York: Longman.

Demir, M. Bacanli, H. \& Tarhan, S. . 2011. Quadruple Thinking Critical Thinking. Journal of Social and Behavioral Sciences. 12. 545-551.

Direktorat Jenderal Pendidikan Tinggi dan Badan Nasional Pendidikan. 2014. Revisi Peraturan Menteri Pendidikan dan Kebudayaan Republik Indonesia tentang Standar Nasional Pendidikan Tinggi (SNPT). Jakarta.

Dwijananti, P. \& Yulianti, D. 2010. Pengembangan Kemampuan Berpikir Kritis Mahasiswa Melalui Pembelajaran Problem Based Instruction pada Mata Kuliah Fisika Lingkungan. Jurnal Pendidikan Fisika Indonesia. 6. 108-114.

Fallis, A . 2013. Penerapan Model Pembelajaran Problem Solving dalam Kelompok Kecil untuk Meningkatkan Kemampuan Berfikir Kritis dan Hasil Belajar. Journal of Chemical Information and Modeling. 53(9). 1689-1699.

Hadi, Rahmini. 2007. Dari Teacher Centered Learning ke Student Centered Learning Perubahan Metodologi Pembelajaran di Perguruan Tinggi. Jurnal Pemikiran Alternatif Pendidikan. 12 (3). 408-419.

Hillman, Wendy. 2003. Learning How To Learn: Problem Based Learning. Autralian Journal of Teacher Education. 28(2).

Ikhsan, M. \& Rizal, S. 2014. Penerapan Model Pembelajaran Berbasis Masalah untuk Meningkatkan Kemampuan Berpikir Kritis dan Disposisi Matematika Siswa. Jurnal Pendidikan. 71-82.

Lai, Emily R. 2011. Critical Thinking A Literature Review. Journal of Critical Thinking. 149.

Lasry, N. Charles, E. \& Whittaker, C. 2014. When Teacher Centered Instruction are Assigned to Student Centered Classrooms. Journal of Physical Review Special Topics-Physics Education Research. 10 (1).

Lestari, K. E. 2014. Implementasi Brain-Based Learning untuk Meningkatkan 
Kemampuan Koneksi dan Kemampuan Berpikir Kritis serta Motivasi Belajar Siswa SMP. Jurnal Pendidikan UNSIKA. 2 (1). $36-46$.

Lewy, Zulkardi. \& Aisyah, Nyimas. 2009. Pengembangan Soal untuk Mengukur Kemampuan Berpikir Tingkat Tinggi. Jurnal Pendidikan Matematika. 3 (2). 1528.

Liliasari. 2000. Pengembangan Keterampilan Berpikir Kritis untuk Mempersiapkan Calon Guru IPA Memasuki Era Globalisasi. Proceeding National Sciences and Mathematics Education. Seminar Science and Mathematic Education Development in Global Era. Yogyakarta: JICA - IMSTEP FMIPA UNY.

Mayer, R. E. 2002. Multimedia learning. Journal of Psychology of Learning and Motivation. 41. 85-139.

Millah, E. S., Budipramana, L. S., \& others. 2012. Pengembangan Buku Ajar Materi Bioteknologi di Kelas XII SMA IPIEMS Surabaya Berorientasi Sains, Teknologi, Lingkungan, dan Masyarakat (SETS). Jurnal Mahasiswa Teknologi Pendidikan. 1(1).

Park, S. \& Artmer, P. 2007. Impact of Problem Based Learning (PBL) on Teachers Beliefs Regarding Technology Use. Journal of Research on Technology Education. 40 (2). 247-267.

Persson, A. C. Fgrenius, A. \& Bergdahl, B. 2010. Perspectives on Using Multimedia Scenarios in PBL Medical Curriculum. Jounal of Medical Teacher. 32 (9). 766772.

Rahayu, Sri. Murtiati, Tri. \& Refirman. 2014. Web Based Learning Media Development in Cardiovascular System Human Anatomy and Physiology Subject. Journal of International Conference on Reasearch, Implementation and Education of Mathematics and Sciences. 8 (1). 91-95.

Rudd, Rick D. 2011. Defining Critical Thinking. Journal of Inquiry: Critical Thinking Across the Disciplines. 26 (1). 38-46.

Santoso, Singgih. 2015. SPSS 20 Pengolah Data Statistik di Era Informasi. Jakarta: PT Elex Media Komputindo.
Smarabawa, I., Arnyana, I. B., \& Setiawan, I. 2013. Pengaruh Model Pembelajaran Sains Teknologi Masyarakat Terhadap Pemahaman Konsep Biologi dan Keterampilan Berpikir Kritis Siswa SMA. Jurnal Pendidikan IPA. 3(1).

Sugiarto, Bambang. 2013. Efektivitas Model Pembelajaran Learning Cycle 5E dengan Strategi Motivasi ARCS pada Materi Transportasi ditinjau dari Ketuntasan Belajar Siswa, Aktivitas Belajar Siswa, Respon Siswa terhadap Pembelajaran, dan Kemampuan Pengelolaan Pembelajaran. http://lppm.uns.ac.id (diakses pada tanggal 15 Juli 2016).

Sukardi, D. 2012. Metode Penelitian Pendidikan. Jakarta: PT Bumi Aksara.

Tim Penyusun Kurikulum Prodi Pendidikan Biologi FKIP UMS. 2013. Dokumen Kurikulum Berbasis KKNI Prodi Pendidikan Biologi FKIP UMS. Surakarta: Universitas Muhammadiyah Surakarta.

Wilson, Jennifer. 2012. Thinking Critically about Critical Thinking. Journal of Educational Philosophy and Theory. 44 (5). 464-479. 